fibula hinged to a La Tene coil. Elsewhere in the barrow were numerous fragments of Romano-British pottery and a small bronze hook. The exploration of Cuckhamsley, or Scutchermer Knob, which is known to have been rifled about a hundred years ago, provided no evidence of burial; but a number of fragments of pottery, including finger-tip ware, consistent with a fifth century B.c. dating were turned up, while $2 \mathrm{ft}$. above were potsherds and a fragment of copper or bronze of foliated design. The mound is evidently not a bronze age barrow nor the burial place of a Saxon king; what the purpose of this remarkable construction may have been has not been revealed.

\section{Quaternary Research in Ireland}

EARLY in 1933 a committee entitled "The Committee for Quaternary Research in Ireland" was founded under the chairmanship of Dr. R. Lloyd Praeger, with Prof. H. J. Seymour as treasurer and Mr. A. Farrington as secretary, the personnel of the Committee being representative of all the scientific bodies and universities of Ireland. The Committee succeeded in enlisting the support of Irish scientific societies, the universities and the Free State Government. The object of the research is to establish a chronology for late-glacial and post-glacial deposits in Ireland, and to study the history of the Irish flora and fauna. Prof. K. Jessen of Copenhagen, with his assistant $\mathrm{Mr}$. H. Jonassen, was invited to take charge of the research. One of the most important aspects of the scheme as conceived by the Committee is the training of Irish students from the universities in the methods developed in northern Europe, so that research centres may be permanently established in the country. Work was begun in the present summer, the first site to be examined being the wellknown bog at Ballybetagh in south Co. Dublin where many remains of Megaceros Giganteus have been found during the last hundred years. An extended tour will also be made for the uxamination of deposits in many other districts throughout Ireland. A list of well-dated recent archæological finds from peat bogs, compiled by Dr. A. Mahr, Director, National Museum, Dublin, forms the basis of this tour.

\section{Expeditions of the Smithsonian Institution, I933}

OwING to the period, variable in duration, but usually not inconsiderable, which must elapse before it is possible to publish in full the details of the valuable field-work which is carried out by the Smithsonian Institution in astrophysies, geology, biology and anthropology, the annual exploration pamphlet issued by the Institution is of considerable interest, as giving an early authoritative account of the various expeditions sent out during the year. The latest issue (Publication 3235), for example, which covers the activities of 1933, records the establish. ment of a new solar observing station on Mount St. Catherine, Sinai (G. C. Abbott), and deseribes the work of the Norcross-Bartlett Arctic Expedition (Capt. R. A. Bartlett), of a deep-sea expedition to PuertoRico (Paul Bartsch), a search for extinct marine mammals in Maryland (Remington Kellogg), particulars of the Hancock expedition to Galapagos (Waldo L. Schmidt), and zoological collecting in Siam (Hugh M. Smith). The greater part of the publication, however, is devoted to the activities of members of the Smithsonian staff in the investigation of the archæology and ethnology of the American Indian, the former a subject in which great progress has been made in recent years by the systematic application of scientific methods of excavation and correlation of results. Dr. Frank H. Roberts, Jr., has continued his excavations of Pueblo sites in the south. western United States, in which the development of Pueblo culture and more particularly of the Pueblo dwelling is being revealed. Dr. Walter Hough has also been engaged in studying an important aspect of Pueblo culture by tracing ancient canals in Arizona, while an earlier phase of Indian history has been illuminated by Mr. F. Setzler's cave and mound explorations in Texas and Louisiana. Dr. W. D. Strong has been engaged in the study of the archæology of Honduras and the Bay islands; while Miss Frances Densmore in her studies of Floridan music and Mr. John Harrington by oral inquiry among ancient members of Californian tribes have recorded material which, but for their activities, would shortly have been lost beyond recovery.

\section{Electrification of the Suburban Railways of Copenhagen}

Tre population of Copenhagen and its suburbs is about 800,000 and they are served by a number of railways, the most important belonging to the State Railway. The problem of electrification presented special difficulties as Denmark is dependent on imported coal for its electric power supply. During recent years, an appreciable amount of electric power has been transmitted from Sweden by 25,000 volt cables which pass under the Sound. When the problem of supply was first investigated, the choice narrowed down to 3,000 volts or 1,500 volts direct current. The latter was chosen, as, although the cost of the overhead equipment was greater, the cost of equipping the cars was less. Hence, when in the future the number of cars is increased, the cost will be less. An account of the system is given by $J$. Kristensen in the Electrical Times of August 23. $\mathrm{He}$ says that all the lattice masts are galvanised, as although it is more expensive than painting it is far more durable. Electrically, the whole system is divided into sections connected through line disconnecting switches. To prevent the electrolysis of neighbouring pipes, extensive precautions are taken. The use of stone ballast keeps the resistance between rail and earth very high, and the resistance of the return system is made as small as possible by joints of heavy copper wire electrically welded to the rails. To prevent interference with telegraph and telephone wires, these have been effectively insulated and placed as far away from the rails as possible. The smallest train is called a 'half-train' and is made up of two motor coaches with a 'trailer' between. It has a seating capacity of 250, and standing room for 200 more. The line Frederiksborg-Klampenborg was opened in April, and the line Copenhagen-Hellerup in May. 